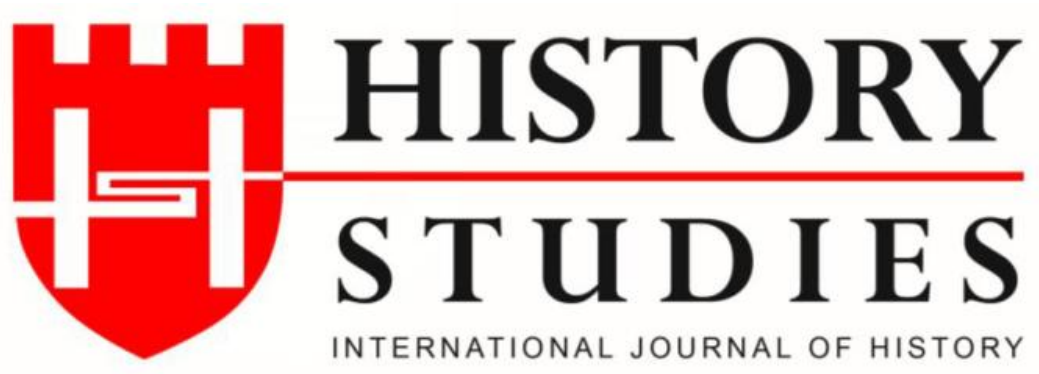

ISSN: 13094173 (Online) 1309 - 4688 (Print)

Volume 12 Issue 3, June 2020

DOI Number: 10.9737/hist.2020.864

Araştırma Makalesi

Makalenin Geliş Tarihi: 17.04.2020 Kabul Tarihi: 04.05.2020

Atıf Künyesi: Mehmet Dağlar, “Safevî Bürokrasisinde Seyyidler (1524-1629)”, History Studies, 12/3, Haziran 2020, s. 999-1010.

\title{
Safevî Bürokrasisinde Seyyidler (1524-1629)
}

\author{
Sayyids in the Safavid Bureaucratic Structure (1524-1629)
}

\author{
Dr. Mehmet Dağlar \\ ORCID No: 0000-0003-3044-4991 \\ Iğdır Üniversitesi
}

Öz: Seyyidler müslüman hükümdarlar tarafindan sürekli hürmet görmüş ve önemli görevlere getirilmiştir. Hükümdarların Peygamber soyundan gelen seyyidlerle yakın ilişki kurması meşruiyetlerinin güçlenmesini sağlamıştır. Safeviler kuruluş yıllarından itibaren çeşitli zümreleri bünyesine katarak gelişmiş ve bürokratik yapısını inşa etmiştir. Konar-göçer kabilelere dayanan bir devletin yeterli derecede devlet adamına ihtiyacı olduğu ortaya çıkmıştır. Askeri bürokrasiyi şekillendiren Türkmenler Safevilerin sivil ve dini bürokrasisi için yetersiz kalmıştır. Safevî Devleti bu sorunu İranlı bürokratlarla çözmeye çalışmasına rağmen resmi mezhep olan Şiiliğin gelişmesi için seyyid ulema sorunun çözülmesine daha fazla yardımcı olmuştur. Seyyidler Safevilerde önemli makamlara getirilerek devletin yapılanmasına katkıda bulunmuştur. Çalışmamızda Safevî Devleti'nin bürokratik anlamda şekillendiği yaklaşık yüz yıllık dönem içerisinde seyyidlerin konumu ele alınmıştır.

Anahtar Kelimeler: Safeviler, Seyyid, Şiilik.

Abstract: Sayyids were constantly respected by muslim rulers and were brought to important positions. The fact that the rulers had a close relationship with the sayyids of the prophet's lineage strengthened their legitimacy. Safavids has built its advanced and bureaucratic structure by incorporating various zones since its foundation. It turns out that a state based on the nomadic tribes needed sufficient statesmen. The Turkmens, who shaped the military bureaucracy, were insufficient for the civil and religious bureaucracy of the Safavids. Altough Safavid State attempted to solve this problem with Iranian bureaucrats for the development of Shi' ite, which is the official sect, sayyid ulema helped to solve the problem. The Sayyids were brought to important authorities in Safavids and contributed to the stucture of the state. In our study, the location of the sayyids in the nearly one hundred-year period in which Safavid state was shaped bureaucratically was discussed.

Keywords: Safavids, Sayyid, Shiism.

\section{Giriş}

Safevî şahlarının Şiileştirme faaliyetleri içerisinde en büyük destekçileri ulema olmuştur. Ulema içerisinde ise seyyid kökenli olanlar ayrı bir yere sahiptir. Seyyidlerle ilişkilerini geliştirmek, onları himaye etmek Safevî hükümdarlarının iktidar alanlarını genişlettiği gibi 
ihtiyaç duyulan sivil ve dini bürokrasinin de gelişmesini sağlamıştır. Humusun ${ }^{1}$ seyyidlere $^{2}$ verilmesi ve onlara verilen önemli görevler şahların meşruiyetlerini güçlendirmeye katkıda bulunmuştur. Safevî Devleti'nde seyyidlerin önemli mevkilere getirildiği ve hükümdarlarla iyi ilişsiler geliştirdikleri görülmüştür. Safevi hükümdarlarının manevi huzurlarını sağlayan en önemli unsurlardan biri peygamber soyu ile yakınlık kurma gayreti olmuştur. Bu nedenle Safeviler İran'da bulunan seyyidler ile yakından ilgilenmişler, seyyid türbelerini koruyarak meşruiyet kazanmaya çalışmışlardır.

Safevî Devleti'nin resmî ideolojisini yansıtan en önemli kaynaklardan olan İskender Beg Münşî’nin Tarih-i Alem Ara-yı Abbasi'de seyyidlerden 'sadat-ı azam zürriyet-i tayyibin ve tahirin' şeklinde bahsetmiştir. ${ }^{2}$ Bu ifadeler Safevilerin seyyidlere verdiği önemin göstergesidir. Safevilerden önce İran'a gelerek yerleşen ve halk arasında saygın bir konuma sahip olan seyyidlerin Safevî Devleti kurulduktan sonra da İran'a göçleri devam etmiştir. Safevîlerde önce İran'a gelen seyyidler yerleşik olarak bilinen seyyid aileleridir. Bu aileler Deştekî, Şerifî, Encuyî, Nimetullahî, Esterabadî, Nurbahşî, Muş'aşî, Rezevî, Seyfî, Şehristanî, Mar'aşî gibi seyyid aileleridir. Safevi Devleti'nin kuruluşundan sonra gelenler ise Kemune, Behranî, Amilî, Kerekî, Cezayirî gibi ailelerdir. Bunlar Safevî hükümdarlarının daveti üzerine İran'a gelerek yerleşen ve önemli vazifelere getirilen ailelerdir. ${ }^{3}$

Safevî İran’ında seyyid kökenli ulemanın toplumda daha etkili olması ve fetvalarının daha muteber kabul edilmesi de saygınlıklarını arttırmıştır. Özellikle Safevilerin kuruluşundan sonra İran'a göç eden seyyidler Şiî geleneğin yayılmasında oldukça etkili olmuştur. ${ }^{4}$ Seyyidlere olan teveccühün temel sebeplerinden biri Safevî hükümdarlarının maneviyatlarını peygamber soyu ile bağ kurarak takviye etmek istemeleridir. Seyyid kökenli birçok alim dini ve siyasi bürokrasi içerisinde görevlendirilmiştir. Safevilerin seyyidlerle bağ kurarken Hz. Ali ile Hz.Fatma'ya ulaşan bir neseb zinciri kurmaya gayret göstermişlerdir. ${ }^{5}$ Dini ve sivil bürokrasi içerisinde görevlendirilen seyyidler Safevî resmi ideolojisinin ihtiyaç duyduğu alanlarda büyük bir boşluğu doldurmuştur.Çalışmamızda Safevilerin dini bürokrasinin kurumsallaştığı Şah Tahmasb (1524-1576) döneminden başlayarak Şah Abbas (1587-1629) dönemine kadar seyyidlerin saltanat ile ilişkileri işlenmiştir.

\section{1.Şah Tahmasb Döneminde Seyyidler}

Safevî Devleti'nin kurucusu ve ilk hükümdarı olan Şah İsmail'in vefatının ardından yerine geçen oğlu Şah Tahmasb (1524-1576), İran'da Şiiliğin yayılması ve yerleşmesi için seyyidlerin nüfuzundan yararlanmıştır. Seyyidlik iddiasını devletin temel politikası haline getiren Tahmasb, seyyidlerle akrabalık kurarak elini güçlendirmeye çalışmıştır. Bu amaçla Yezd seyyidlerinden Şah Nimetullah Yezdî’nin kızını H.962 (1554/1555) yılında oğlu İsmail

\footnotetext{
${ }^{1}$ Şiiler arasında seyyidlerin hakkının gözetilmesi, insanlar arasında itibarlarının korunması için humusun seyyidlere dağtılması yaygın bir anlayıştır. Kelime anlamı beşte bir olan humus, ganimetlerden ve bu hükümde olan mallardan kamu adına toplanan bir vergidir. Sünnî ve Şî̂ fikıh alimleri humus konusunu farklı yorumlamıştır.Bkz. H. Yunus Apaydın, "Humus", Türkiye Diyanet Vakfi İslam Ansiklopedisi,C.18, İstanbul 1998, s.365; Humusun kime verilmesi gerektiği hakkında tartışmalar için ayrıca Bkz. E. Ruhi Fığlalı, Çağımızda itikadi İslam mezhepleri, Ankara, 1996, s.171.

${ }^{2}$ İskender Beg Münşî, Tarih-i Âlem Ara-yı Abbasi, neşr: İrec Afşar, Tahran: Müessese-i İntişarat-1 Emir Kebir, 1387, s. 143.

${ }^{3}$ Hasan Allahyarî, "Tehlil-i Tarih-i Muhacerat-1 Sadat Ez İran be Hind der Asr-1 Safevi: Ba Takid-i ber Teneşhay-1 Deruni ve Biruni-yi Sadat", Mütalaat-ı Tarih-i Ferhengi, 7/28, 1395, s.3

${ }^{4}$ Zeynep Hatun Kordî- Tahire Kordî, "Nakş-1 Sadat ve Ulema der Hukuk-u Şehrvendi-yi Asr-1 Safevi”, Fasılname-i Hukuk-ı Milel, 6/ 23, ( Paiz 1395), s.67 ve s.74.

${ }^{5}$ Seyyid Haşim Akaçeri- Hasan Allahyari, “Tehvil-i ve Tenv'i-i Mefhumu Siyadet der asr-1 Safeviyye”, Mütalaat-ı Tarih-i Islam, Y11:3, (1390), s.21
} 
Mirza ile evlendirmiştir. Safevi hanedanından Hatice Sultan ise Meşhed ayan ve seyyidlerinden Ebu Talib'in oğlu Mirza Ebu'l- Kasım ile evlendirilmiştir. ${ }^{6}$

Tahmasb'in seyyidlere olan ilgisine İran'a gelen Venedikli seyyah Membré bizzat şahit olmuştur. Tebriz'i ziyaret ederken Tahmasb'ı da gören Membré, Şah'ın otağının yanında Sam Mirza ve Behram Mirza'nın çadırlarının olduğunu, onların yanında da Uskuye seyyidlerinin çadırlarını gördügünü, Şah Tahmasb nezdinde Uskuye seyyidlerinin nasıl itibara sahip olduğunu anlatmıştır. ${ }^{7}$ Seyyidlere gösterilen ihtiram sayesinde iktidarını sağlamlaştıran Tahmasb seyyidlere önemli görevler tevcih etmiştir. Şah Tahmasb devrinin önemli seyyidlerinden olan İsfahan'ın 'sadat-ı Hüseyniyesinden ve nakibü'l nükebası'ndan Mir Gıyaseddin Mahmud, en yüksek dini makam olan sadaret rütbesine getirilmiştir. Mir Gıyaseddin İsfahan'da birçok emlak sahibiydi. Mirza Muhammed ve Muhammed Emin adlı oğulları da devirlerinin önemli alimlerinden oldukları için Tahmasb'ın teveccühüne nail olmuşlardır. ${ }^{8}$

Şah Tahmasb, İran'da halkın saygı gösterdiği Şah Nimetullah-1 Veli'nin ${ }^{9}$ soyundan gelen Nimetullahî seyyidlerini de devlet içerisinde önemli görevlere getirmiştir. Tahmasb devrinin önemli seyyidlerinden olan şeceresi Şah Nimetullah-1 Veli'ye ulaşan Mir-i Mirân-1 Yezdî, Şâh'ın yakın çevresinde bulunmuştur. ${ }^{10}$ Rey'de İkamet eden Nurbahşî seyyidlerinden Şâh Kasım Nurbahşî de Şâh'ın teveccühünü görerek Nurbahşî seyyidleri silsilesini temsil etmiştir.. ${ }^{11}$ Mar'aşî seyyidlerinden olan Mir Al'a Nebi ise Kazvin'de kazıaskerlik yapmıştır. Gilan'ın fethinin ardından da Gilan Sadareti makamına getirilmiştir. ${ }^{12}$ Seyyidlerin işlerini yürüten özellikle sahte seyyidlerin ortaya çıkmasını tespit eden Nakibler de Şah Tahmasb döneminde sadaret gibi önemli bir makama getirilmiştir. Mesela İsfahan seyyidlerinden ve Nakiblerinden Mir Kıvamüddin Hasan, Cemalleddin Muhammed Esterabadî ile birlikte Sadaret makamına getirilmiştir. $^{13}$

Volume 12

Tahmasb döneminde önemli seyyidlerden birisi de Mir Fahreddin Semakî̀'dir. Esterabad seyyidlerinden olan Semakî devrinin ulema ve müderrislerindendir. Giyaseddin Mensur Şirazî’nin tilmizindendir. 'El Heyat-ı Tecrid' adlı esere bir haşiye yazmıştır. ${ }^{14}$ Tahmasb, önemli dini görevlerin yanı sıra pişnemaz (imam) gibi daha düşük düzeyde görevlere de seyyidleri getirmiştir. Necef Seyyidlerinden Mir Rahmetullah’1 Dergah-1 Mualla'da Pişnemaz görevine getirmiştir. ${ }^{15}$

\footnotetext{
${ }^{6}$ Seyyid Haşim Akaçeri, Mukaddeme-i Ber Münasebat-ı Din u Devlet Der Iran Asr-ı Safevi, Tahran 1389, s.125.

${ }^{7}$ Michele, Membré, Mission to The Lord Sophy of Persia (1539-1542), Translated with Introduction and Notes by A.H. Morton, London: Published by The School of Oriental and African Studies, University of London, 1993, s.20.

${ }^{8}$ Münşî, age, s.144.

9 Şah Nimetullah-1 Veli, 26 Aralık 1330 yılında Halep’te doğmuştur. Soyu İmam Cafer-i Sadık'a dayanmaktadır. Yedi yıl Mekke'de Abdullah b. Es'ad el-Kafî'nin yanında kalarak İbnü'l Arabi'nin fikirlerini öğrendi. Daha sonra Mısır'a giderek Kahire'de Kaygusuz Abdal'ın da kaldığı Mukattam Dağı'nda halvete çekildi. Kahire'de geçirdiği üç yıl içinde Kalenderilikle tanışan Nimetullah, ayrıca Şeyh Bedreddin'in şeyhi olan Seyyid Hüseyin Ahlatî'den gizli ilimler öğrendi. Suriye, İran, Irak ve Azerbaycan'ı dolaşarak Maveraünnehir'e gitti. Türkmenler arasında oldukça ünlenen Şah Nimetullah'ın siyasi amaçları olduğuna dair bilgiler Timur'a ulaşınca Maveraünnehir'i terk etmesi istendi. Ardından Meşhed ve Herat'a gitti. Şah Nimetullah'ı takip eden Nimetullahiler Safeviler döneminde tamamen Şiileşmiştir. Bkz. M.Erol Kılıç, "Nimetullah-1 Veli", Türkiye Diyanet Vakfi İslam Ansiklopedisi, C.33, İstanbul 2007, s.133-134..

${ }^{10}$ Münşî, age, s.145.

${ }^{11}$ age, s.145.

${ }^{12}$ Münşî, age, s.146.

${ }^{13}$ Sam Mirza-y1 Safevi, Tuhfe-i Sami, Neşr: Fatma Engurani, Tahran, 1389, s.32.

${ }^{14}$ Münşî, age, s.146.

15 age, s.146.
} 
Şah Tahmasb'ın seyyidlere verdiği önemin kanıtlarından birisi de çocuklarının eğitimini seyyidlere tevdi etmesidir. Tahmasb, Emir Seyyid Cürcanı̂’nin soyundan gelen Seyyid Emir Murtaza'yı Şahzadelerin sorumluluğuna getirmiştir. ${ }^{16}$ Şah Tahmasb devrinde seyyidler devlet ve toplum nezdinde itibarlarını korumuşlar ve Safevilerin gelişmesine katkıda bulunmuşlardır. Toplumun önde gelenlerinden olan seyyidler İran'ın muhtelif şehirlerinde önemli görevler üstlenmiştir. Babürlü hükümdarı Hümayun İran'a geldiğinde Meşhed'e uğrayarak İmam Rıza'nın türbesini ziyaret etmek istemiştir. Onu Meşhed'de seyyidler karşılayarak gereken ilgi ve alakayı göstermiştir. ${ }^{17}$

Şah Tahmasb seyyid ulemaya destek vererek onların Şiî fikhını geliştirmelerine katkıda bulunmuştur. Müçtehid Şeyh Ali bin Abdulali'nin torunu olan Mir Muhammed Bakır Damad ise Meşhed'de ilim ve irfan öğrenerek Safevi ordusunda görev yapmıştır. İlimde oldukça ilerleyen Mir Muhammed, fakihler tarafindan fetvası muteber sayılan bir alim olmuştur. ${ }^{18}$ Tahmasb, seyyidlerin çeşitli yeteneklerinden de faydalanmıştır. Mesela Kirman seyyidlerinden olan Mirek Münş̂̀’ inşa makamına getirilmiştir. ${ }^{19}$ Siyasi görevler alarak arabuluculuk yapan seyyidler şahların otoritesinin korunmasına yardımcı olmuştur. Şah Tahmsab'ın otoritesini sarsan Elkas Mirza isyanında Necef Seyyidleri onu isyandan vazgeçirmeye çalışmıştır. İmam Rıza Asitanesinin Hadimbaşı olan Mir Abdülazim Mazendaranî de Elkas'ı ikna etmek için uğraşmıştır. ${ }^{20}$ Elkas Mirza isyanında İsfahan seyyidlerinin nakibi şehrin kelanteriyle ${ }^{21}$ işbirliği yaparak Elkas Mirza'nın şehre girmesini engellemiştir(1548). Elkas Mirza İsfahan'dan ayrılarak Fars'a yönelmiş Yezd'in Has kalesine vararak orada katliam yapıp şehri talan etmiştir. Oradan Şuşter'e geçip kenti kuşatmış ancak Şahmir lakabıyla olan Seyyid Şemseddin Esedullah'ın oğulları Mir Seyyid Ali ve Mir Abdülvehhab memleketlerini savunmuşlardır. ${ }^{22}$ Ayrıca Tahmasb, Elkas Mirza isyanında İmam Rıza Asitanesinin Hadimbaşı olarak görev yapan Seyyid Mir Abdülazim Baberkanî’yi Elkas Mirza’ya elçi olarak göndermiştir. ${ }^{23}$

Tahmasb'ın seyyidlerle olan yakın ilişkisi onların önemli mevkilere getirilmelerini sağladığı gibi aralarında güven tesis edilmesini de sağlamıştır. Eşikağası Seyyid Bey Kemune, Tahmasb tarafından hareminin başına getirilmiştir. Şah Tahmasb döneminde ilmi görevlerin yanısıra bürokratik makamlara da bazı seyyidlerin getirildiğini görmekteyiz. 1561'de Müstevfi-yi Memalik Hoca Kasım Natanzî ölünce onun makamına 'Mir Seyyid Müstevfí -yi Şehristanî-yi İsfahanî' lakabıyla meşhur olan Mir Gıyaseddin Mahmud tayin edilmiştir. ${ }^{24}$

Tahmasb dönemi seyyidlerinden Mir Seyyid Ali de toplumsal ahlakın denetleyicisi, emri marufun uygulayıcısı konumunda olan muhtesib olarak atanmıştır. Mir Seyyid Ali özellikle sahtekarların başına takılarak toplumda küçük düşmelerini sağlayan 'Tahta külah',25

\footnotetext{
${ }^{16}$ Emir Mahmud Handmir, İran Der Ruzgar-ı Şah İsmail ve Şah Tahmasb-ı Safevi (Zeyl-i Habibü’s Siyer), Tahran 1390, s.190.

${ }_{17}$ age, s.214.

${ }^{18}$ Münşî, age, s.147

${ }^{19}$ Abdi Beğ Şirazî, Safeviler: Tekmiletü'l Ahbar, Tercüme ve Notlar: Şefaattin Deniz- Hasan Asadi, İstanbul, 2009, s.79.

${ }^{20}$ Budak Münşi Kazvinî, Cevahirü'l Ahbar, neşr: Muhsin Behram Nejad, Tahran: Vezaret-i Ferhengi ve İrşad-1 İslami,1378, s.204.

${ }^{21}$ Kelanter; İran'da asayiş ve adaletin sağlanmasından sorumlu olan kişiler için kullanılmaktadır. Bkz. Ayşe Atıcı Arayancan, Karakoyunlu Hükümdarlarından Cihanşah ve Dönemi (Siyaset-Teşkilat-İktisad-Din-Kültür) 1438-1467, (Ankara Üniversitesi Sosyal Bilimler Enstitüsü Basılmamış Doktora Tezi), Ankara 2010, s. 256.

${ }^{22}$ Şirazî, age, s.94

23 age, s.95.

${ }^{24}$ age, s.112.

${ }^{25}$ Tahta külah; Safevi iranında "emri maruf nehyi münker" anlayışla bağlantılı olarak yapılan bir uygulamaydı. Toplum içerisinde ahlaki kurallara riayet edilmesi, sahtekarların cezalandırılması amacıyla ibret-i alem için suçlu
} 
uygulamasını organize etmiştir. ${ }^{26}$ Tahmasb döneminde Seyyidler önemli makamlara getirilerek taltif edilmiştir. Bu dönemde İmam Rıza Asitanesi mütevellisi olan Mir Ebu'l Vali’nin görevinden ayrıldıktan sonra Tebriz'e gelerek 'Evkaf-ı Gazanı̂'nin mütevellisi olarak atandığı bilinmektedir. $^{27}$

Arap coğrafyasından gelen seyyidler Safevilerin ilim adamlarına ihtiyaç duyduğu bir dönemde önemli bir açığı kapatmıştır. Tahmasb döneminde Şiiliğin güçlenmesi için İran'a gelerek önemli görevler üstlenen Muhakkık-1 Kereki'nin kızından olan Mir Seyyid Hüseyin (Müçtehid Ziyaeddin Hasan'ın oğlu) Cebel-i Âmil'den Erivan'a göç etmiş ve oradan da Erdebil'e giderek şeyhülislamlık ve müderrislik görevlerini ifa etmiştir. Mir Seyyid Hüseyin daha sonra Şah Tahmasb'ın yanına gelerek hürmet görmüştür. ${ }^{28}$

Dini makamların yanı sıra sivil bürokrasi içerisinde de seyyidler görevlendirilmiştir. Tahmasb seyyidlerle kurduğu yakın ilişki sonucu kelanter makamına da bazı seyyidleri getirmiştir. Mir Seyyid Seracceddin Ali Kumî, Kum kelanteri olarak atanmıştır. ${ }^{29}$ Tahmasb, humus'un seyyidlere dağıtılarak, onların toplumsal saygınlıklarının korunmasını istemiştir. Tahmasb, humus dağıtılmasını Ehlibeytin koruyucusu olduğu izlenimi yaratmak için önemsemiştir. ${ }^{30}$ Safeviler döneminde geliştirilen Şî̂ fikhında da seyyidlere zekat verilmesi yasaklandığı için humusun seyyidlere verilmesi teşvik edilmiştir. ${ }^{31}$ Safevî dini hiyerarşisi içinde en yüksek makam olan sadrlar eyaletlerde şiiliğin yayılmasından sorumlu oldukları gibi humus toplama yetkisine de sahiplerdi. Bu nedenle Tahmasb, sadr makamına getireceği kişilerin özellikle seyyidler arasından seçilmesine özen gösterilmiştir. ${ }^{32}$

Ehlibeyt'i öven şiirler yazan bazı seyyidlerin Tahmasb döneminde de etkin olduklarını görmekteyiz. Hz. Ali için kasideler yazan ve Hüseyin Baykara döneminin sadrlarından olan Şah Tahmasb dönemine kadar bu görevini sürdüren Seyyid İbrahim, Özbek saldırılarında öldürülmüştür. ${ }^{33}$ Şah Tahmasb'ın Ö̈zbeklerle olan mücadelesi seyyidleri de etkilemiştir. Esterabad seyyidlerinden olan Herat Kadısı Seyyid Hasan Özbek Ubeyd Han'ın emriyle Şiî olduğu gerekçesiyle (behane-i teşeyyu) öldürülmüştür. ${ }^{34}$

Şah Tahmasb döneminde Safevilerin resmi ideolojisi Şiiliğe aykırı olduğu kanaatine varılan bazı seyyidler ise Sünnilikle suçlanarak gözden düşürülmüştür. Tebriz'in ünlü Lale seyyidleri özellikle Tahmasb döneminde açıç̧a Sünnî olmakla suçlanarak baskı görmüşlerdir. ${ }^{35}$ Şiraz seyyidlerinden Şerifî ailesinden olan ve Şah II.İsmail döneminde saltanatla iyi ilişkiler geliştirerek sadr makamına getirilen Mirza Mahdum'un babası Mir Şerif Şirazî, Tahmasb

kişilere tahta külah giydirirdi. Bu uygulama toplum içinde tören şeklinde yapılırdı. Suçlunun aşağılanması amaçlanırdı. Oktay Efendiyev, Azerbaycan Safevi Devleti (16.Yüzyıl), Çev: Ali Asker, İstanbul, 2018, s.312

${ }^{26}$ Kazvinî, age, s. 258

${ }^{27}$ Efendiyev, age, s.283.

${ }^{28}$ Münşî, age, s.145.

${ }^{29}$ Seyyid Haşim Akaçeri-Hasan Allahyarî, "Caygah-1 Sadat der Mansıb-1 Kelanteri der Devre-i Safeviyye”, Cami-i Sinasi-yi Tarihi, Say1:1 (1394), s.41.

${ }^{30}$ Parsadust, Şah Tahmasb-1 Evvel, s.824.

${ }^{31}$ Akaçeri- Allahyarî, "Tehvil-i ve Tenv'i-i Mefhumu Siyadet s.12; Norman Calder, "Khums in Shi'i Jurisprudence, From the Tenth to the Sixteenth Century A.D", Bulletin of the School of Oriental and African Studies, University of London, 45/1, (1982), s.39-40; Ehlibeyt'e zekatın yasaklanmış olması hakkında Bkz. Murat Sarıcık, Osmanlı İmparatorluğu'nda Nakibü'l- Eşraflık Müessesesi, Ankara 2003, s.13.

${ }^{32}$ Namıg Musalı, "I. Şah İsmail'in İdari- Askeri ve İçtimai- İktisadi Politikaları Üzerine Bazı Notlar ve Değerlendirmeler", Akademik Tarih ve Düşünce Dergisi, İlkbahar, 5/14, (2018), s.20.

${ }^{33}$ Sam Mirza, age, s.44.

${ }^{34}$ Sam Mirza, age, s.50.

35 Muhammed Taki Meşkuriyan - Ali Ekber Caferî "Sadat-1 Lale-i Tebriz der Güzar-1 be Asr-1 Safevi”, Fasılnamei İlmi, Sal-1 Bist-u Pencum, Devre-i Cedid, Zımıstan, Şomare 28, (1394), s.264. 
tarafından Şiraz kelantarı olarak atanmıştır. Mir Şerif, kelantarlık görevinin ardından kadı ve vezaret gibi çeşitli makamlara da getirilerek saltanatla iyi ilişkiler geliştirmiştir. ${ }^{36}$ İran'ın meşhur Mar'aşî seyyidlerini de dini bürokrasi içerisinde istihdam eden Tahmasb özellikle Şuşter bölgesinde Şiiliğin yayılması için de Mar'aşilerden yararlanmıştır. Mir Şahmir unvanı verilen Mir Şemseddin Mar'aşî, Sadr görevine getirilmiştir. Şuşter'in Şiileşmesi için gayret gösteren Tahmasb Şuşter'deki Mar'aşi seyyidlerini başkent Kazvin'e davet ederek onlara ihtiram göstermiştir. ${ }^{37}$

\section{2.Şah II.İsmail ve Şah Muhammed Dönemlerinde Seyyidler}

Safevî Devletinin en ilginç hükümdarlarından olan Şah II. İsmail kısa hükümdarlığı döneminde tam anlamıyla iktidar sahibi olamayarak Kızılbaş emirler ve Şiî ulema ile ters düşmüştür. Şah İsmail'in dini politikası ulema ile arasının açılmasına ve hükümdarlığının sonuna giden süreci hızlandırmıştır. Şah İsmail'in seyyidlerle olan ilişkisi de dini siyasetinin bir parçasıdır. Şah İsmail'in dini siyaseti, din adamları ile ilişkisi ve Safevî Şiiliğine aykırı davranışları seyyidlerle olan ilişkilerinde de yansımıştır. Şah İsmail tahta geçer geçmez Sünnî bir seyyid olan Mirza Mahdum Şerifî’ye hürmet ve iltimas göstermesi Şiî ulemanın tepkisini çekmesine sebep olmuştur.Şah İsmail'in seyyidlerle olan ilişkisi mezhep siyaseti ile bağlantılıdır. Şah İsmail politikası gereği Şii ulema ile seyyidlerin suyurgallarına sınırlamalar getirerek onların ekonomik açıdan zayıf düşmelerine sebep olmuştur. ${ }^{38}$

Şah İsmail'in Şiî ulema ile yaşadığı anlaşmazlık ve Safevî şiiliğine aykırı olan teberra etme geleneğini kaldırmaya çalışması bu anlaşmazlığı derinleştirmiştir. Şah İsmail, Şiî ulemaya karşı desteğini Seyyid kökenli Mirza Mahdum Şerifi'yi yanına alarak çözmeye çalışmıştır. Tahmasb'ın saltanatının son yıllarından Şah'ın kızı Perihan Hanım tarafından himaye edilen Mirza Mahdum, İsmail Mirza'nın Şah olmasından sonra sadaret makamına getirilmiştir Şiraz seyyidlerinden olan Mirza Mahdum Şerifi'nin babası ve dedesi Şah İsmail'e ve Şah Tahmasb'a hizmet etmişler ve Safevilerle akarabalık kurmuşlardır. Anne tarafından ise soyu Şah Tahmasb'ın vezirlerinden Kadı Cihan Seyfi'ye dayanır. ${ }^{39}$

Şah İsmail'in dini siyasetinin şekillenmesinde Seyyid Mirza Mahdum'un etkisi büyüktür. Şah İsmail'in özellikle teberriyanlara ${ }^{40}$ karşı uyguladığı siyasette Mirza Mahdum etkili olmuştur. Mirza Mahdum Şerifî, Şah İsmail'e Timur'un ulema ile ilişkisini anlatarak o dönemde ulemanın Sünnî olduğunu ve Timur'un başarılı bir hükümdar olmasının bunun sonucu olduğunu söylemiştir. Şah İsmail'e de büyük bir hükümdar olmak istiyorsa Sünniliği ihya etmesi gerektiğini telkin etmiştir. Şah İsmail, Mirza Mahdum'un tavsiyelerini önemseyerek dini siyasetini şekillendirmiştir. ${ }^{41}$ Şah İsmail tahta çıtıktan sonra kendisine muhalefet eden kesimler içerinde yer alan ve devletin kuruluş yıllarından itibaren Safevilere hizmet eden Necef Seyyidlerinden Kemune ailesinin bir ferdi olan Seyyid Muhammed Kemune'nin oğlu Seyyid Bey'i Sultan Haydar Mirza'nın taraftarlarından olduğu için hapsetmiştir. Şah bu davranışıyla iktidarına muhalif olan bütün kesimleri baskı altına aldığı gibi seyyidleri de kontrol altına almıştır. ${ }^{42}$

\footnotetext{
${ }^{36}$ Kioumars Ghereghlou, "A Safavid Bureaucrat in The Ottoman World : Mirza Mahdum Sharifi Shirazi and the Ouest For Upward Mobility in the İlmiye Hierarchy”, Osmanlı Araştırmaları, L.III, (2019), s.158.

${ }^{37}$ Kazvinî, age, s.185.

${ }^{38}$ Hamidreza Sefakiş, Safeviyan der Gozeşti Tarih, İntişarat-1 Sahn, Tahran 1390, s.398.

${ }^{39}$ Ghereghlou, agm, s.157-160.

40 Teberriyanlar özellikle ilk üç halifeye beddua etmek İmamlara methiyeler dizmek için teşkilatlandırılmış bir gruptur. Bkz. Menuçehr Parsadust, Şah Tahmasb-ı Evvel, Tahran:Şirket-i Sihami, 1391, s. 81.

${ }^{41}$ Akaçeri, age, s.180.

${ }^{42}$ Hasan-1 Rumlu, Ahsenü’t Tevarih, Cild-i Sevvom, neşr: Abdülhüseyin Nevaî, Tahran 1389, s.1526.
} 
Şah Tahmasb döneminde önemli görevlere getirilen bazı seyyidlerin daha sonra iktidarla anlaşamayarak komşu ülkelere iltica ettiği görülmektedir. Seyyidlerin göçünde Şah İsmail’in Sünniliğe olan meyli etkili olmuş olabilir. Şehzadelerin eğitimleriyle meşgul olan Esterabad seyyidlerinden Mir Muhammed Mümin Esterabadî, İsmail Mirza'nın tahta çıkmasıyla beraber güney Hindistan'a giderek Dekken'de hüküm süren Şiî Kutubşahların hizmetine girmiş orada vezirliğe yükselmiştir. ${ }^{43}$

Safevilerde Şah İsmail döneminden itibaren İran'a davet edilmeye başlanan Şii ulema devletin resmi mezhebi olan Şiiliğin yerleşebilmesi için önemli görevlere getirilmiş̧tir. Safevi şahları ulemaya verdikleri destek sayesinde iktidarlarını sağlamlaştırmıştır. Şah Tahmasb'ın Muhakkık-1 Kerekî, Şah İsmail'in Mirza Mahdum Şerifî gibi alimleri en yakınlarında bulundurma siyasetini devam ettiren Şah Muhammed Hudabende (1578-1587), Mir Şemseddin Kirmanî'ye ihtiram göstermiştir. Şah tarafından Mir Şemseddin Muhammed'e 'Tevliyet-i Evkaf-ı Hazret-i Çeharde masum' (ondört masum vakfı mütevellisi) görevi verilmiştir. ${ }^{44}$

Şah Muhammed'in itibar gösterdiği Mir Şemseddin, bürokrasideki atamalarda etkili olarak önemli bir konuma gelmiştir. Erdebil asitenesi mütevellisi olan Seyyid Ebul Vali Encu'yu Şah ordusunun Şeyhülislamı görevine getirerek kendisine 100 bin tümen maaş bağlanmıştır. Mir Ebu'l Vali Encu Şah Tahmasb devrinde Meşhed Asitanesinin mütevellisi iken Meşhed hakimi Şah Veli Sultan ile aralarında anlaşmazlık çıkınca bu görevinden alınarak Erdebil'e gönderilmişti. Muhammed Hudabende döneminde Mir Şemseddin tarafından taltif edilmiş ve Şeyhülislam görevine getirilmiştir. Mir Ebu'l Vali H.994 (1585-1586) senesinde sadaret makamına getirmiştir. Bu atamaları gerçekleştiren Mir Şemseddin'in Şah Muhammed Hudabende üzerinde ne kadar etkili olduğunun göstergesidir. ${ }^{45^{3}}$

Ebul Vali Encu sadr görevindeyken yaptırdı̆g 1 binaya “Devlethane-i sadrü'l islam ve'l

Volume 12

Issue 3

June

2020 müminin Mir Ebu'l Vali" yazdırmıştır. ${ }^{46}$ Mir Şemseddin Kirmani Sadr, Şah Muhammed Hudabende üzerinde büyük nüfuz sahibi olmuştur. Sürekli Şah ile beraber bulunan Kirmani’ye değerli eşyalar hil'at vb verilerek 'divan-ı Sadaret-i Aliyye' unvanı verilmiştir. ${ }^{47}$ Mali işlerde önemli bir makam olan 'istifa-yı memalik' görevine de Emir Şah Gazi İsfahanî getirilmiştir. Adli işlerin sorumlusu olarak kadıaskerlik makamına bir başka seyyid Şah Muzafereddin Ali Encu (Sadat-1 ekabir-i Şiraz) getirilmiştir. ${ }^{48}$

Safevi Devletinin kuruluş yıllarından itibaren şahlar tarafından hürmet gören Kemune seyyidleri Şah Muhammed Hudabende döneminde de itibarlı konumunu sürdürmüştür. Devrin önemli alimlerinden olan Seyyid Süleyman Kemune, Şah Hudabende döneminin önemli alimlerinden olmuştur. ${ }^{49}$ Şah Muhammed'in itibar gösterdiği Mar'aşî seyyidleri de Kazvin'de bulunan kutsal mekânların sorumluluğuna getirilmiştir. ${ }^{50}$

Şah Tahmasb döneminde dini işlerin yürütülmesinde etkili olan Muhakkık-1 Kerekî’nin soyundan gelen Seyyid Hüseyin Kerekî, Hudabende döneminde önemli bir din adamı olarak saltanatla iyi ilişkiler geliştirmiştir. ${ }^{51}$ Münşî, Seyyid Hüseyin'i devrinin içtihad kapısı ünlü

${ }^{43}$ Münșî, age, s.146

${ }^{44}$ Akaçeri, age, s.204.

${ }^{45}$ Akaçeri, age., s.205.

${ }^{46}$ Akaçeri, age., s.205. ve 245.

${ }^{47}$ Kumî, age., s.663.

${ }^{48}$ Kumî, age., s.662-663.

${ }^{49}$ Kadı Ahmet el- Kumî, Hülasatü't Tevarih, Cild-i Evvel, neşr: İhsan İşraki, Tahran: İntişrat-1 Danişgah-1 Tahran, 1383 , s.268

${ }^{50}$ J. Andrew Newman, Safavid Iran Rebirth of a Persian Empire, New York, 2009, s.42

${ }^{51}$ Dewin J.Stewart, "Safevi İran'ına Amili Ulemanın Göçüne Dair Notlar”, (Çev: Habib Kartaloğlu), e-Makalat Mezhep Araştırmaları Dergisi, 9/2, 2016, s.284. 
alimlerinden biri olarak tanımlar. Seyyid Hüseyin'e "Seyyidü'l muhakkrk-in ve seyyidü'l müddakeyn varisi ulüm ve enbiya ve mürselin ve hatemü'l müçtehid" unvanı verilmiştir. ${ }^{52}$ Tahmasb üzerinde büyük etkisi olan Kerekî'nin soyundan gelen Seyyid Hüseyin Kerekî Muhammed Hudabende döneminde Kazvin Şeyhülislamı olarak görev yapmıştır. Şah Muhammed'in emriyle önemli görevlere getirilen Seyyid Hüseyin, 1586 yılındaki Kızılbaş ayaklanmasında arabuluculuk yapmıştır. ${ }^{53}$

Şah Muhammed devrinde yaşayan bütün din adamları ihtiram görmeyerek saltanatla sorun yaşayanlar da olmuştur. Safevi Şiiliğine aykırı davranan bazı seyyidler bertaraf edilmeye çalışılmıştır. Şah İsmail'in ölümünden sonra yaşanan kargaşa ortamında Şah'ın en önemli destekçilerinden olan Mirza Mahdum Şerifî teberriyanların hedefi haline gelmiştir. Safevi Şiiliğinin yerine Sünniliği ikame etmeye çalışan Mirza Mahdum, Şiî ulemanın ve Kızılbaş emirlerin tepkisini çekmiştir. ${ }^{54}$ Şah İsmail'in halifelere lanet edilmesini yasaklamasında etkili olan Mirza Mahdum, teberriyyanlar tarafından zindandan çıkarılıp at meydanına getirilmiştir. Mirza Mahdum'a karşı tepkili olan teberriyanlar onu öldürmek üzereyken Şah Muhammed'in kızkardeşi Perihan Hanım ve mülazımları tarafından kurtarılmıştır. Teberriyanlardan kurtulan Mirza Mahdum Şerifî Osmanlı Devleti'ne sı̆̆ınmıştır. Mirza Mahdum Şerifî'ye gösterilen düşmanlık Şah İsmail'in dini siyasetinin kabul görmediğinin de göstergesidir. ${ }^{55}$

Kelanterlik görevi de Muhammed Hudabende döneminde de bazen seyyidlere verilmiştir. Seyyid Mirza Abdülhüseyin Tebriz kelanteri yapılmıştır. ${ }^{56}$ Bir diğer seyyid Mir Siraceddin Ali Kumî adlı alim de Kum Kelanterliği görevine getirilmiştir. ${ }^{57}$ Muhammed Hudabende devri önemli alimlerinden olan Kum seyyidlerinden ve ayanlarından olan Mir Haşim Kumî de itibar gören alimlerdendir. ${ }^{58}$

\section{3.Şah Abbas Dönemi Seyyidler}

Şah Muhammed'in ardından tahta çıkan Şah Abbas (1587-1629) döneminde de İran'da yaşayan seyyidler önemli makamlara getirilerek devletten saygı ve hürmet görmüşlerdir. Safevî hükümdarları içerisinde Ehlibeyt taraftarı olarak görülen ve meşruiyetini bu politika üzerinden sağlamlaştıran Şah Abbas kendini 'Kelb-i Asitan-ı Ali' olarak tanımlayarak mührüne de bu yazıyı kazıtmıştır. ${ }^{59}$ Sadaret, tevliyet, nikabet, ihtisab gibi önemli dini ve sivil mansıblara seyyidler getirilerek Şah Abbas'la yakın ilişki içerisinde olmuşlardır. Uzun yıllar boyunca devlete hizmet eden Kemune seyyidleri ve Rezevî seyyidler Şah Abbas tarafından teveccüh gösterilen seyyid aileleridir. Şah Abbas, Kazvin seyyidlerinden (Sadat-1 Seyfi-yi Kazvin) olan Mirza Burhan'ın oğlu Kazî Han olarak meşhur Mir Ma'zuleddin Muhammed'i Sadaret

\footnotetext{
${ }^{52}$ Münșî,age., s.458

${ }^{53}$ Devin J.Stewart, "The First Shaykh al-Islam of The Safavid Capital Qazvin", Journal of The American Oriental Society, 116/ 3, (July-September 1996), s.395.

${ }^{54}$ Andrew Newman, “The Role of the Sadat in Safavid Iran: Confrontation or Accommodation?", Oriente Moderno, Nuova Serie, Anno 18(79), Nr.2, (1999), s.587.

${ }^{55}$ Kumî, age.,s.657

${ }^{56}$ Seyyid Haşim Akaçeri-Hasan Allahyari, “Caygah-1 Sadat der Mansıb-1 Kelanteri der Devre-i Safeviyye”,Cami-i Sinasi-yi Tarihi, 7/1, 1394.42.

${ }^{57}$ Kumî, age, s. 270

${ }^{58}$ Kumî, age,s.705.

${ }^{59}$ Sefakiş, age, s.399; Faruk Sümer, "I. ve II. Abbas Devirleri”, Türk Dünyası Araştırmaları Dergisi, 69, (Aralık 1990), s.23
} 
makamına getirerek geleneksel politikaya uygun davranmıştır. Kazî Han dini işlerin yanı sıra siyasi işlerle de alakadar olmuştur. ${ }^{60}$

Şah Abbas'ın seyyidlere gösterdiği hürmet İran'dan başka ülkelere iltica eden seyyidlerin tekrar ülkelerine dönmeleri için firsat olmuştur. Dekken'de bulunan Kutubşahların hizmetine geçerek önemli makamlara ulaşan Mir Muhammed Emin ve amcası Mirza Razî Sadr Dekken'den Şah Abbas'ın yanına gelerek hizmetine girmek istemişlerdir. Mezkur seyyidler Muhammed Kulı Kutubşah'ın vefatından sonra ülkelerine geri dönerek Mazenderan'da Şah Abbas'a sığınmışlardır. ${ }^{61}$

Şah Abbas'ın teveccüh gösterdiği seyyidlerden Seyyid Kazî Sultan, tevliyet makamından önce İsfahan Daruga'sı olarak görev yapmıştır. Kemune seyyidlerinden Seyyid Beg Kemune de Şah Abbas'ın mühürdarı olarak görevlendirilmiştir. Ayrıca Kemune Seyyidlerinden Seyyid Hüseyin Kemune, Şah Abbas'dan itibar görerek kendisine birçok mal ve emlak bağışlanmıştır. Natanz seyyidlerinden Seyyid Mir Ebu'l Mualla Natanzi "Vezir-i gulaman-ı meclis nivis-i şah" ve Mir Feyzullah ise "vezir-i gulaman-ı tenburzen" makamına getirilmiştir. ${ }^{62}$ Şah Abbas, 1621 yılında Bahaaddin Amilı̂’nin vefatının ardından İsfahan Şeyhülislamı olarak Mir Muhammed Bakır Damad'ı atamıştır. Babası Esterabad kökenli bir seyyid, annesi ise Kerekî ailesinden olan Mir Muhammed, hem Amilî geleneğin hem de İranlı seyyidlerin temsilcisi olarak saltanatın destekçisi ve önde gelen alimlerinden olmuştur. ${ }^{63}$

Şah Abbas döneminde İran'a ilim ve seyahat amaciyla Medine Seyyidleri göç etmiştir. İran'a gelen seyyidler genellikle İmam Riza'nın kabrini ziyaret, ilmi faaliyette bulunmak ve hükümdardan maddi destek görmeyi amaçlamıştır. Medine seyyidleri özellikle İsfahan'a yerleşerek evlilikler yaparak yerli halkla kaynaşmışlardır. Şah Abbas, Medine Seyyidlerinden Hüseyin bin Hasan bin Ali'yi İran'a davet ederek meclisinde onunla Şiî fikhı üzerine konuşmuştur. Şah, Seyyid Hüseyin'e ilgi ve hürmet göstererek kendisine 1500 tümen bağışlamıştır. ${ }^{64}$ Şah Abbas, Medine seyyidlerinden İran'a gelen Süleyman bin Muhammed'i de yanına davet ederek kendisine saygı ve hürmet göstermiştir. Şah, Seyyid Süleyman'dan Medine seyyidlerinin durumu hakkında bilgi almıştır. İsfahan'a gelen Medine seyyidlerinden Amir bin Bedevi'ye ise Şah Abbas tarafindan iki köy vakfedilerek kendisine y1lda 20 bin tümen Tebrizî bağışlanmıştır. ${ }^{65}$ Şah Abbas döneminde bazı seyyidlerin İmamiyye Şiiliğine aykırı davrandıkları için hedef haline geldikleri de görülmüştür. Noktevî olan Mir Seyyid Ahmet Kaşî, Kaşan'da etrafına birçok insanı topladığı gerekçesiyle Şah Abbas tarafından öldürülmüştür. Şah Abbas'ın bu tavrı seyyid de olsa devletin resmi ideolojisine aykırı davranan kişilerin ortadan kaldırıldığının göstergesidir. ${ }^{66}$

Şah Abbas'ın baskılarından kurtulmak için Seyyid Ahmet Kaşî’nin taraftarı olan birçok Noktevî seyyid (Sadat-1 noktevi) Hindistan'a kaçmıştır. ${ }^{67}$ Safevi Devletinin kuruluş yıllarından itibaren en çok uğraştığı ve Safevi saltanatını tehdit eden Muş'aşa seyyidleri Şah Abbas devrinde de faaliyetlerine devam etmiştir. Muş'aşa seyyidlerinin reisi Seyyid Mübarek, Arap

\footnotetext{
${ }^{60}$ Akaçeri, age, s.246;Said Amir Arjomand, "The Clerical Estate and the Emergence of a Shi' ite Hierocracy in Safavid Iran: A study in Historical Sociology", Journal of The Economic and Social History of Orient, 28/2, (1995), s.170.

61 "Hubb-1 vatan ve arzu-yu amedeni İran”. Bkz.Akaçeri, agm, s.242

${ }^{62}$ Akaçeri, agm, s.242.

${ }^{63}$ Stewart, "Safevi İran'ına Amili Ulemanın Göçüne Dair Notlar", s.280.

${ }^{64}$ Resul Caferiyan, "Revabit-1 Sadat-1 Ben-i hüseyin-i Medine ba İsfahan-1 Safevi ber Esas-1 İtlaat-1 Tuhfetü'l Ezhar", Ayine-i Miras, 4/ 81, Tarihsiz, s.16.

${ }^{65}$ Caferiyan, "Revabit-1 Sadat-1 Ben-i Hüseyin-i Medine", s.17.

${ }^{66}$ Münşî, age, s.476

${ }^{67}$ Allahyarî, "Tehlil-i Tarih-i Muhacerat-1 Sadat Ez İran be Hind der Asr-1 Safevi”, s.6.
} 
kabileleri tarafından destek görerek 1594 yılında Dizful ve Şuşter şehirlerini kuşatmıştır. Seyyid Mübarek, Safevi devletinin mücadele halinde olduğu Özbeklerle irtibat haline girerek Özbek Abdülmuminin Han ile mektuplaşarak Safevilerin aleyhine ittifak arayışına girmiştir. ${ }^{68}$

Şah Abbas, çeşitli devletlere elçi olarak gönderdiği kişileri de seyyidler arasından seçmiştir. Güney Hindistan'ın Dekken bölgesinde bulunan Nizamşahlar Devletine elçi olarak Merağa seyyidlerinden Derviş Bey gönderilmiştir. Ancak Derviş Bey yolda giderken Şiraz'da vefat edince yerine Mahmudi Bey gönderilmiştir. ${ }^{69}$

Şah Abbas da sadaret makamına seyyidlerin getirilmesi geleneğine uyarak bu uygulamayı sürdürmüştür. Safevilere kuruluş yıllarından itibaren destek veren Encuyî seyyidleri Şah Abbas döneminde de itibar görmüştür. Şah Abbas'ın babası Muhammed Hudabende devrinde Sadr olarak görev yapan Ebu'l Vali Encu bu görevine devam etmiştir. Şah Abbas döneminde Mirza Razî Damad, Sadreddin Muhammed, Refieddin Muhammed ve Ref'i Şehristanî sadr olan diğer seyyidlerdir. ${ }^{70}$ Kelanter makamına da bazı seyyidler getirilmiştir. Mir Ebu'l Mualla Nişaburî, Nişabur kelanteri olarak atanmıştır. Şah Abbas Seyyid Mir Şemseddin Ali Muhtariyye'yi Sebzivar'a oğlu Mir Mahmud'u da Horasan'a kelanter olarak atamıştır. ${ }^{71}$

\section{Sonuç}

Timurlu ve Akkoyunlu devletlerinin mirasını devralan Safeviler yeni gelişen bürokrasi içerisinde özellikle yerli İranlı nüfustan faydalanmıştır. Ancak dini hayatın Şiiliğe göre şekillenmesi seyyidlerin Safevi şahları tarafından teveccüh görmesinin yolunu açmıştır. Şiî ulemaya duyulan ihtiyaç neticesinde İran'a davet edilen ulemanın içerisinde birçok seyyid kökenli alim olduğu gibi Safevilerden önce de İran'da yaşayan seyyidler Safevilerin önemli destekçileriden olmuşlardır.Safeviler itibarlarını korumaları için humus gibi tartışmalı bir gelir kaynağının seyyidlere tahsis edilmesini sağlayarak maddi açıdan rahat bir konuma gelmelerini sağlamıştır.Seyyidlerin toplum içerisinde itibarlarını korumak için şahlar onlara saygıda kusur etmemiştir. Seyyid ulema sivil ve dini bürokrasisi içerisinde önemli görevlere getirilmiştir.Dini bürokrasinin gelişmesinde önemli katkılarda bulunan seyyidler Şiiliğin halk tabanına yayılmasını kolaylaştırmıştır. Peygamber soyuna gösterilen hürmet halkın Safevilere bağlılığını arttırmış, şahların iktidarı güçlenmiştir. Seyyidlerin Şiiliğe bağlı olmaları veya muhalefet potansiyeli taşımamalarına özen gösterilmiştir.Devletin resmi mezhebine aykırı davranan seyyidler ise bertaraf edilmiştir.Kızılbaş Türkmen kabilelerin büyük bir bağlılıkla desteklediği Safevi Devleti Şiiliğin kurumsallaşmasına paralel olarak seyyidlerden faydalanmıştır. Şahların seyyidlik iddiasını kullanarak meşruiyet sağlamaları seyyidlerin daha fazla yardım görmesini ve toplum nezdinde saygınlıklarını arttırmıştır.

\section{Kaynaklar}

ABDİ BEĞ ŞİRAZÎ, Safeviler: Tekmiletü'l Ahbar, Tercüme ve Notlar: Şefaattin Deniz- Hasan Asadi, İstanbul, 2009.

AKAÇERİ, Seyyid Haşim - ALLAHYARÎ, Hasan, "Tehvil-i ve Tenv'i-i Mefhumu Siyadet der asr-1 Safeviyye", Mütalaat-ı Tarih-i İslam, Tabıstan, Sal-1 Sevvom, 1390, s.7-26.

\footnotetext{
${ }^{68}$ V. Minorsky, “Müşa'şalar”, Milli Ĕ̌itim Bakanlığ İslam Ansiklopedisi, C.8, İstanbul 1997, s.841.

${ }^{69}$ Münşî, age, s.951.

${ }^{70}$ Zeynep Hatun kordi- Tahire Kordi, "Nakş-1 Sadat ve Ulema der Hukuk-u Şehrvendi-yi Asr-1 Safevi”, Fasılname-i Hukuk-ı Milel, 6/ 23, (Paiz 1395), s. 77.

${ }^{71}$ Akaçeri-Allahyari, "Caygah-1 Sadat der mansıbı kelanteri”, s.42.
} 
AKAÇERİ-Seyyid- ALLAHYARÎ, Haşim Hasan, "Caygah-1 Sadat der Mansıb-1 Kelanteri der Devre-i Safeviyye", Cami-i Şinasi-yi Tarihi, Devre-i heft, Şomare yek, Behar u Tabıstan 1394, s.37-57.

AKAÇERİ, Seyyid Haşim, Mukaddeme-i Ber Münasebat-ı Din u Devlet Der Iran Asr-ı Safevi, Tahran 1389.

ALLAHYARÎ, Hasan "Tehlil-i Tarih-i Muhacerat-1 Sadat Ez İran be Hind der Asr-1 Safevi: Ba Takid-i ber Teneşhay-1 Deruni ve Biruni-yi Sadat", Mütalaat-ı Tarih-i Ferhengi, Sal-1 heftum, Şomare bist u heştum, Tabistan, 1395, s.1-22

APAYDIN, H. Yunus, "Humus", Türkiye Diyanet Vakfi İslam Ansiklopedisi ,C.18, İstanbul 1998, s.365-369.

ARAYANCAN, Ayşe Atıc1, Karakoyunlu Hükümdarlarından Cihanşah ve Dönemi (SiyasetTeşkilat-İktisad-Din-Kültür) 1438-1467, (Ankara Üniversitesi Sosyal Bilimler Enstitüsü Basılmamış Doktora Tezi), Ankara 2010.

ARJOMAND, Said Amir, "The Clerical Estate and the Emergence of a Shi' ite Hierocracy in Safavid Iran: A study in Historical Sociology", Journal of The Economic and Social History of Orient, 28/2, 1995, s.169-219.

CALDER, Norman, "Khums in Shi'i Jurisprudence, From the Tenth to the Sixteenth Century A.D”, Bulletin of the School of Oriental and African Studies, University of London, 45/1, 1982, s.39-47.

EFENDIYEV, Oktay, Azerbaycan Safevi Devleti (16.Yüzyll), Çev: Ali Asker, İstanbul, 2018.

Volume 12

EL- KUMÎ, Kadı Ahmet, Hülasatü't Tevarih, Cild-i Evvel, neşr: İhsan İşraki, Tahran: İntişrat-1 Danişgah-1 Tahran, 1383.

FIĞLALI, E. Ruhi, Çağımızda İtikadi İslam mezhepleri, Ankara, 1996.

GHEREGHLOU Kioumars, "A Safavid Bureaucrat in The Ottoman World : Mirza Mahdum Sharifi Shirazi and the Ouest For Upward Mobility in the İlmiye Hierarchy", Osmanll Araştırmaları, L.III, 2019, s.153-194.

HANDMIR, Emir Mahmud, Iran Der Ruzgar-ı Şah İsmail ve Şah Tahmasb-ı Safevi (Zeyl-i Habibü's Siyer), Tahran 1390.

HASAN-I RUMLU, Ahsenü't Tevarih, Cild-i Sevvom, neşr: Abdülhüseyin Nevaî, Tahran 1389.

KAZVINÎ,, Budak Münşî, Cevahirü'l Ahbar, neşr: Muhsin Behram Nejad, Tahran: Vezaret-i Ferhengi ve İrşad-1 İslami,1378.

KILIÇ, M.Erol, "Nimetullah-1 Veli”, Türkiye Diyanet Vakfı İslam Ansiklopedisi, C.33, İstanbul 2007, s.133-135.

KORDÎ Zeynep Hatun - KORDÎ, Tahire, "Nakş-1 Sadat ve Ulema der Hukuk-u Şehrvendi-yi Asr-1 Safevi”, Fasılname-i Hukuk-ı Milel, Sal-1 Şeşem, Şomare 23, Paiz 1395, s.65-80.

MEMBRÉ, Michele, Mission to The Lord Sophy of Persia (1539-1542), Translated with Introduction and Notes by A.H. Morton, London: Published by The School of Oriental and African Studies, University of London, 1993. 
MEŞKURIYAN Muhammed Taki - CAFERÎ Ali Ekber, "Sadat-1 Lale-i Tebriz der Güzar-1 be Asr-1 Safevi”, Fasılname-i Illmi, Sal-1 Bist-u Pencum, Devre-i Cedid, Zımıstan, Şomare 28,1394, s.246-272.

MINORSKY, V, “Müşa'şalar”, Milli Eğitim Bakanlı̆̆ İslam Ansiklopedisi, C.8, İstanbul 1997, s.839-843.

MUSALI, Namıg, "I. Şah İsmail'in İdari- Askeri ve İçtimai- İktisadi Politikaları Üzerine Bazı Notlar ve Değerlendirmeler", Akademik Tarih ve Düşünce Dergisi, İlkbahar, 5/14, 2018, s.1-46.

MÜNŞÎ İskender Beg, Tarih-i Âlem Ara-yı Abbasi, neşr: İrec Afşar, Tahran: Müessese-i İntişarat-1 Emir Kebir, 1387.

NEWMAN, Andrew, "The Role of the Sadat in Safavid Iran: Confrontation or Accommodation?", Oriente Moderno, Nuova Serie, Anno 18(79), Nr.2, 1999, s.577-596.

NEWMAN, J. Andrew, Safavid Iran Rebirth of a Persian Empire, Newyork: 2009.

PARSADUST Menuçehr, Şah Tahmasb-ı Evvel, Tahran:Şirket-i Sihami, 1391.

CAFERIYAN, Resul "Revabit-1 Sadat-1 Ben-i hüseyin-i Medine ba İsfahan-1 Safevi ber Esas-1 İtlaat-1 tuhfetü'l Ezhar", Ayine-i Miras, Sal-1 Çeharem, Şomare 4, Behar: 81, Tarihsiz.

SAM MIRZA-YI SAFEVI, Tuhfe-i Sami, Neşr: Fatma Engurani, Tahran, 1389.

SARICIK, Murat, Osmanlı Imparatorluğu'nda Nakibü'l- Eşraflık Müessesesi, Ankara 2003.

SEFAKİş Hamidreza, Safeviyan der Gozeşti Tarih, İntişarat-1 Sahn, Tahran 1390.

STEWART, Devin J, “The First Shaykh al-Islam of The Safavid Capital Qazvin", Journal of The American Oriental Society, Volume 116, Number 3, July-September 1996.

STEWART, Dewin J, “Safevi İran'ına Amili Ulemanın Göçüne Dair Notlar”, (Çev: Habib Kartaloğlu), e-Makalat Mezhep Araştırmaları Dergisi, 9/2, 2016.

SÜMER, Faruk, "I. ve II. Abbas Devirleri”, Türk Dünyası Araştırmaları Dergisi, 69, Aralık, 1990. 